\title{
PEMASARAN JASA PENDIDIKAN IAIN ANTASARI (PERSPEKTIF MARKETING MIX JASA PENDIDIKAN)
}

\author{
Ahmad Juhaidi* \\ IAIN Antasari Jalan Ahmad Yani km. 4.5 Banjarmasin \\ e-mail: ahmadjuhaidi@iain-antasari.ac.id
}

\begin{abstract}
Competition among institutions of education to make educational services marketing into an interesting study to be observed. This article is the result of quantitative descriptive research with descriptive statistical analysis. The study population was all new students IAIN Antasari in 2013 amounted to 1578 people with a stratified sample of 515 people. This research error rate below 1 $\%$. This study found that the elements of the marketing mix is the reason most dominant freshman academic year 2013/2014 to choose LAIN Antasari is a product (92.12\%) and most do not provide the driving is the promotion element $(62.27 \%)$. Thus, the promotion of which has been implemented so far should be evaluated in order to optimize the marketing of educational services IAIN Antasari .
\end{abstract}

Key Wordss : Product, price, place, promotion, people, physical evidence, and process

\begin{abstract}
Abstrak
Persaingan antarlembaga pendidikan menjadikan pemasaran jasa pendidikan menjadi kajian yang menarik untuk dicermati. Artikel ini merupakan hasil penelitian deskriptif kuantitatif dengan analisis statistik deskriptif. Populasi penelitian ini adalah seluruh mahasiswa baru IAIN Antasari tahun 2013 berjumlah 1578 orang dengan sample berstrata 515 orang. Tingkat kesalahan penelitian ini dibawah 1\%.

Penelitian ini menemukan bahwa elemen bauran pemasaran yang paling dominan menjadi alasan mahasiswa baru tahun akademik 2013/2014 untuk memilih IAIN Antasari adalah produk $(92,12 \%)$ dan yang paling tidak memberikan pendorong adalah elemen promosi $(62,27 \%)$. Dengan demikian, promosi yang telah dijalankan selama ini harus dievaluasi agar lebih optimal dalam pemasaran jasa pendidikan IAIN Antasari.
\end{abstract}

Kata kunci : Produk, price, place, promotion, people, physical evidence, dan process

\footnotetext{
* Penulis adalah Dosen pada Fakultas Tarbiyah dan Keguruan IAIN Antasari Banjarmasin, alumnus Program S3 UPI Bandung tahun 2012
} 


\section{A. PENDAHULUAN}

Pada tiga tahun terakhir, sejak tahun akademik 2010/2011, mahasiswa baru IAIN Antasari mengalami peningkatan yang signifikan. Sebelum tahun 2010, yang calon mahasiswa baru yang mendaftar ujian masuk tidak mencapai seribu pendaftar. Jika dibandingkan dengan jumlah peserta UN SMA/MA, jumlah mahasiswa baru tersebut dapat dilihat pada tabel berikut

TABEL 1 Perbandingan Mahasiswa Baru Dengan Peserta UN

\begin{tabular}{|r|c|c|c|c|c|c|}
\hline & 2008 & 2009 & 2010 & 2011 & 2012 & 2013 \\
\hline $\begin{array}{r}\text { Peserta UN } \\
\text { SMA/MA }\end{array}$ & 18.285 & 20.208 & 20.995 & 21.330 & 22.790 & 24.454 \\
\hline Mhs Baru & 692 & 859 & 1.291 & 1.522 & 1.544 & 1.578 \\
\hline Persentase & $3,78 \%$ & $4,25 \%$ & $6.15 \%$ & $7.14 \%$ & $6.77 \%$ & $6,45 \%$ \\
\hline
\end{tabular}

Sumber :

Dinas Pendidikan Kalsel (online) tersedia http://antarakalsel.com/berita/6810/103-peserta-un-kalsel-tidak-lulus

Dinas Pendidikan Kalsel (online) tersedia http://disdikprovkalsel.info/berita/detail/ 152

Data dan Statistik IAIN Antasari BanjarmasinTahun 2008 s.d. 2012 Bagian Akademik dan Kemahasiswaan

Pada tabel perbandingan peserta UN SMA/MA dengan jumlah mahasiswa baru di atas, dapat dilihat ketidakkonsistenan peningkatan jumlah mahasiswa baru IAIN Antasari pada tahun 2011 dan 2012. Jika jumlah peserta UN SMA/MA disepakati merupakan calon pelanggan utama, meminjam istilah Edward Sallis, seharusnya pada tahun 2012, presentasi lulusan SMA/MA di Kalimantan Selatan di atas 7, 14 \%.

Proses penerimaaan mahasiswa baru tersebut diawali sosialisasi. Dari sudut pandang marketing lembaga pendidikan, sosialisasi dalam bahasa bauran pemasaran dapat disebut promosi (promotion) lembaga pendidikan.Secara umum, proses sosialisasi dilaksanakan secara sistematis. Dengan kata lain, program promosi sudah diprogramkan dan mendapat alokasi dana dari pihak institut. Sosialisasi IAIN Antasari dilakukan dalam tiga bentuk, pertama, penyebaran brosur penerimaan mahasiswa baru. Kedua, sosialisasi ke sekolahsekolah dan mengundang kepala sekolah. Ketiga, publikasi via website.

Keefektifan biaya sosialisasi tersebut dapat dianalisis dengan Cost Effectiveness Analysis (Analisis Keefektifan Biaya). Analis tersebut dapat digunakan jika hasil dari biaya yang dikeluarkan tidak bisa atau sulit dinilai dengan nilai uang. Dengan mengadopsi pendapat Bray (2008), keefektifan biaya dapat dilihat dari perbandingan alokasi dana untuk sosialisasi dengan jumlah mahasiswa baru

Keefektifan biaya sosialisasi $=$ Alokasi Biaya Sosialisasi : Jumlah mahasiswa baru 
Hasil analisis keefektifan biaya dapat dilihat pada tabel berikut

Tabel 2 Keefektifan Biaya Sosialisasi

\begin{tabular}{|r|c|l|l|l|l|}
\hline & 2008 & \multicolumn{1}{|c|}{2009} & \multicolumn{1}{|c|}{2010} & 2011 & 2012 \\
\hline $\begin{array}{r}\text { Alokasi } \\
\text { Dana } \\
\text { Sosialisasi }\end{array}$ & - & 75.000 .000 & 48.975 .000 & 64.975 .000 & 64.975 .000 \\
\hline Mhs Baru & 692 & 859 & 1.291 & 1.522 & 1.544 \\
\hline $\begin{array}{r}\text { Keefektifan } \\
\text { Biaya }\end{array}$ & & 8.7 & 3.8 & 4.3 & 4.2 \\
\hline
\end{tabular}

Pada tabel tersebut tergambar ketidakkonsistenan keefektifan alokasi sosialisasi dengan jumlah mahasiswa baru. Semakin rendah angka keefektifan biaya semakin efektif, sebuah program. Jika menggunakan analisis kefektifan biaya, dapat disebutkan bahwa program sosialisasi yang paling efektif adalah sosialisasi pada tahun anggaran 2010. Pada tahun tersebut, yang diperlukan untuk menarik seorang mahasiswa baru sebesar Rp. 37. 936,-. Bacaan terhadap tabel tersebut dapat diduga bahwa mahasiswa baru (costumer) dalam memilih lembaga pendidikan tidak secara konsisten dipengaruhi oleh sosialisasi tetapi juga oleh aspek lain dari bauran pemasaran. Lebih jauh, pendapat yang ekstrem menyebutkan bahwa promosi jasa pendidikan tinggi tidak memegang peranan penting, bahkan bisa menjadi bumerang bagi pemasaran lembaga pendidikan. (Alma, 2005 :137) Terkait itu, aspek lain juga harus dicermati dalam rekrutmen mahasiswa baru IAIN Antasari. Unsur bauran pemasaran tersebut sering disebut 7P yaitu product, price, place, promotion, people, physycal evidence dan process. (Hidayat \& Machali, 2012, Alma, 2005)

Selain aspek bauran pemasaran tersebut, loyalitas pelanggan juga menentukan bertambahnya pelanggan baru. Salah satu indikasi mahasiswa yang loyal adalah refers otherskeaktifan mereka menyarankan kepada orang lain untuk kuliah di IAIN Antasari. (Griffin, 2002 : 4). Di samping itu, mahasiswa yang loyal juga ditandai dengan "penyampaian positif" atau memberikan informasi yang positif kepada pihak lain. Oleh karena itu, tingkat loyalitas pelanggan juga perlu dicermati dalam konteks proses penerimaan mahasiswa baru khusus dalam konteks menarik mahasiswa baru.

Paparan tersebut diatas menjadi argumen untuk mencermati lebih mendalam tentang penerimaan mahasiswa baru IAIN Antasari ditinjau dari perspektif pemasaran jasa lembaga pendidikan, khusus aspek bauran pemasaran.

\section{B. DEFINISI OPERASIONAL}

Peneliti merasa perlu mendefinisikan beberapa istilah dalam penelitian ini

1. Bauran pemasaran adalah elemen-elemen pemasaran yangharus dikelola dan dipadukan dalam pemasaran jasa pendidikan; 
2. Elemen bauran pemasaran adalah produk (product), biaya (price), tempat (place), promosi (promotion), warga kampus (people), bukti fisik (physical evidence), dan proses (process).

\section{RUMUSAN MASALAH}

Penelitian ini menjawab pertanyaan utama yaitu elemen bauran pemasaran apa yang paling dominan menarik mahasiswa untuk menempuh pendidikan di IAINAntasari?

\section{LANDASAN TEORITIS}

\section{Bauran Pemasaran (Marketing Mix) Jasa Lembaga Pendidikan}

Pemasaran jasa pendidikan tidak bisa dilepaskan dari pola prilaku konsemen. Pola prilaku tersebut dapat dipahami dengan prinsip AIDA + S. Prinsip itu dapat dilihat pada gambar dibawah ini

GAMBAR 2.1

PRINSIP AIDA + S DALAM PEMILIHAN PT

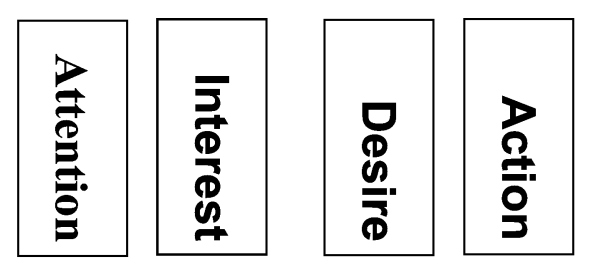

\section{CALON MHS}

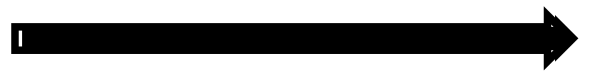

SATISFACTION

Sumber :

Alma : 2005

Pada gambar diatas dapat dilihat bagaimana seorang lulusan memilih sebuah perguruan tinggi. Pola prilaku calon mahasiswa dimulai attention. Mereka memiliki perhatian kepada perguruan tinggi melaluiinformasi dari orang tua, teman, kenalan, surat kabar, atau media lain. Mereka juga memerhatikan perguruan tinggi melalui berbagai berita di televisi atau radio. Kemudian mereka merasa tertarik dengan mencari informasi lebih jauh, menanyakan kepada orang-orang yang dianggap mengetahui (interest). Calon mahasiswa tersebut kemudian berkunjung ke kampus untuk mendaftar dan mengikuti tes. Perilaku itu disebut desire. Setelah lulus test, dia mendaftar ulang dan mengikuti kuliah (action).

Mahasiswa yang telah sekian lama mengikuti kuliah akan muncul perasaan puas (satisfaction) atau tidak puas. Dua sikap pelanggan tersebut menjadi balikan bagi perguruan tinggi dan berdampak pada calon konsumen yang lain.

Pola prilaku tersebut tersebut dapat dipengaruhi oleh bagaimana strategi pemasaran jasa pendidikan dilaksanakan. Strategi yang banyak dikenal adalah bauran pemasaran. 
(marketing mix). Bauran pemasaran pada awalnya dikenal pada kajian ekonomi, kemudian belakangan digunakan pula untuk lembaga pendidikan. Adopsi konsep bauran pemasaran oleh bidang pendidikan didasari pandangan bahwa pendidikan adalah bagian dari layanan jasa sehingga tidak berbeda dengan pemasaran jasa pada bidang lain. Sebagai sebuah layanan jasa, seperti halnya produk jasa lain, pendidikan juga memiliki karakteristik yang tidak jauh berbeda.

Bauran pemasaran (marketing mix) merupakan alat bagi pemasar yang terdiri atas berbagai unsur suatu program pemasaran yang perlu dipertimbangkan agar implementasi strategi pemasaran dan positioning yang ditetapkan dapat berjalan sukses (Lupiyoadi \& Hamdani, 2006: 70). Kotler et al (2002:9) mendefinisikan bauran pemasaran sebagai berikut "marketing mix as a set of controllable, tactical marketing tools that the firm blends to produce the result it wants in the target market". Maksudnya adalah bauran pemasaran merupakan serangkaian unsur-unsur pemasaran yang dapat dikendalikan oleh perusahaan dan dipadukan sedemikian rupa sehmgga dapat mencapai tujuannya dalam pasar sasaran.

The Chartered Institute of Marketing (2009) memahami marketing mix sebagai kombinasi taktik dalam pemasaran. Elemen-elemen bauran pemasaran lebih sebagai bentuk cara dalam pemasaran jasa pendidikan. Perpaduan yang baik antar elemen tersebut akan menunjang keberhasilan menarik calon pelanggan. Memperhatikan satu elemen saja, tanpa kombinasi, tidak akan memberikan pengaruh yang optimal dalam menarik pelanggan, atau dalam pemasaran jasa pendidikan, menarik siswa/mahasiswa.

Dalam konteks pendidikan, bauran pemasaran (marketing mix) adalah unsur-unsur yang sangat penting dan dapat dipadukan sedemikian rupa sehingga dapat menghasilkan strategi pemasaran yang dapat digunakan untuk memenangkan persaingan. Pada awalnya, elemen atau unsur bauran pemasaran adalah empat seperti pada gambar berikut 
GAMBAR 2.2

\section{ELEMEN BAURAN PEMASARAN 4P}

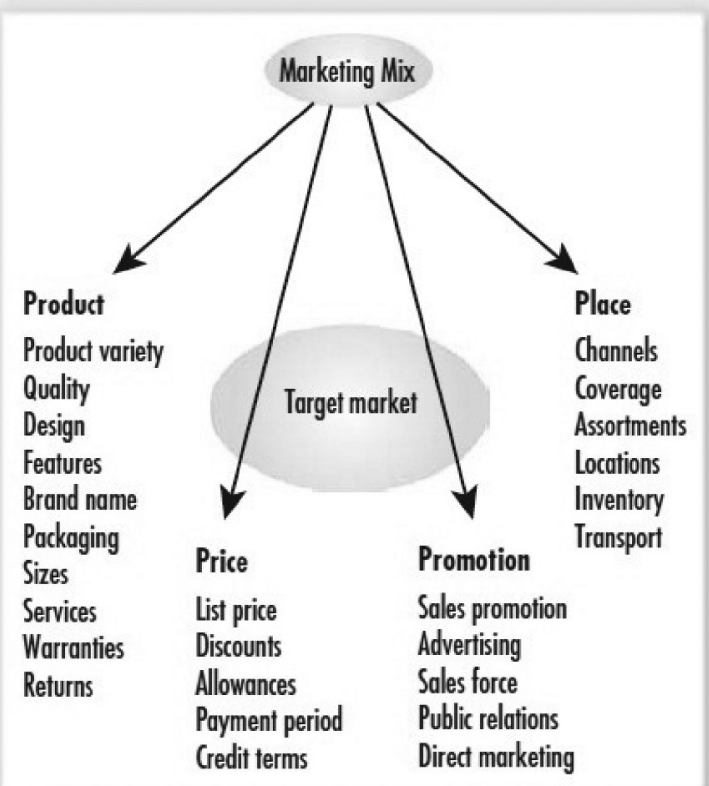

Sumber : Kotler, $2002: 10$

Perkembangan selanjutnya, elemen yang terdapat dalam bauran pemasaran ada tujuh hal yang biasa disingkat dengan $7 \mathrm{P}$ yaitu terdiri dari $4 \mathrm{P}$ tradisional yang digunakan dalam pemasaran barang dan ${ }_{3} \mathrm{P}$ sebagai perluasan bauran pemasaran (The Chartered Instituted of Marketing, 2009). Unsur 4P adalah product (produk); jasa seperti apa yang ditawarkan, price (harga); strategi penentuan harganya, place (lokasi/tempat); dimana tempat jasa diberikan, promotion (promosi) bagaimana promosi dilakukan, sedangkan elemen 3P adalah people (SDM); kualitas, kualifikasi, dan kompetensi yang dimiliki oleh orang yang terlibat dalam pemberian jasa, physical evidence (bukti fisik); saranaprasarana seperti apa yang dimiliki, dan process; manajemen layanan pembelajaran yang diberikan. (Hidayat \& Machali, 2012) 
Elemen 3P tersebut dapat dilihat pada gambar berikut

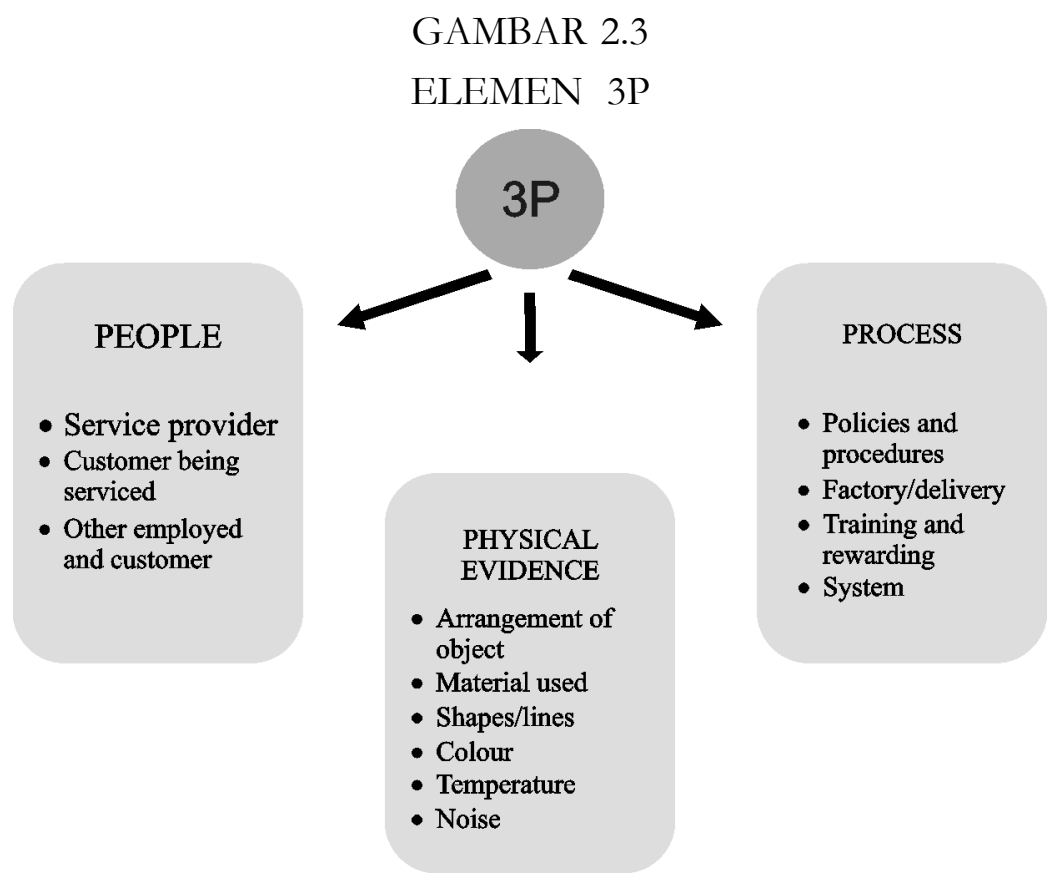

Sumber : Alma, 2005

Terlepas dari tersebut, perdebatan apakah pendidikan harus tetap berdasarkan pasar (market)atau tetap pada tataran ideal sebagai lembaga pendidikan tidak pernah selesai, terutama dikalangan peminat ekonomi pendidikan. Mau tidak mau lembaga pendidikan harus mencermati bahwa masyarakat akan memilih lembaga pendidikan yang diinginkannya dan disisi lain lembaga pendidikan tetap memiliki otonomi sebagai produsen. (John F. Witte, 2000 : 200) Dengan kata lain, lembaga pendidikan, dalam hal ini lembaga pendidikan Islam (baca : IAIN Antasari), harus berada pada posisi berpihak pada market dan tidak melepaskan diri dari kewenangannya sebagai lembaga pendidikan Islam.

\section{Penelitian Terdahulu yang Relevan}

Penelitian tentang pemasaran jasa pendidikan belum banyak dilakukan, khususnya dalam konteks IAIN Antasari. Satu penelitian yang layak disebut disini adalah penelitian yang dilakukan Hariyanto dkk (2007). Penelitian tersebut bertujuan melihat hubungan mahasiswa kuliah di IAIN Antasari dengan aspek bauran pemasaran (marketing mix). Kerangka teoritis yang digunakan dalam penelitian tersebut tidak merujuk pada literatur pemasaran jasa pendidikan, tetapi pada marketing secara umum. Simpulan paling menarik penelitian itu adalah ditemukannya korelasi yang lemah antara keputusan kuliah di IAIN Antasari dengan kualitas produk IAIN Antasari, sedangkan korelasi yang kuat pada promosi, lokasi, kualitas SDM, dan proses. Korelasi negatif ada pada aspek biaya dan sarana. Penelitian dengan analisis regresi itu terlihat ada hal yang janggal pada simpulan. Pada satu sisi, simpulan menyebutkan bahwa produk tidak mempengaruhi 
pilihan untuk kuliah di IAIN Antasari, tetapi pada sisi lain disebutkan mahasiswa kuliah di IAIN Antasari karena lulus pada pilihan pertama (81,7\%). Itu menunjukkan bahwa produk, yaitu jurusan telah memenuhi keinginan calon mahasiswa. Kejanggalan tersebut, sangat mungkin, disebabkan oleh populasi yang diambil dari seluruh mahasiswa, tidak fokus padamahasiswa baru. Responden yang telah lama kuliah akan menjawab pertanyaan dengan jawaban berbentuk evaluasi terhadap aspek dalam bauran pemasaran.

Selain itu, penelitian tersebut juga belum menunjukkan elemen bauran yang masih perlu diperbaiki dalam pemasaran jasa pendidikan IAIN Antasari. Misalnya, penelitian itu belum dapat menjawab pertanyaan bentuk promosi apa yang paling banyak menjadi sumber informasi bagi calon mahasiswa baru. Jawaban yang didapatkan penelitian tersebut hanya menyebutkan bahwa promosi berkorelasi kuat dengan pilihan melanjutkan studi ke IAIN Antasari.

\section{E. METODE PENELITIAN}

Penelitian ini merupakan penelitiandeskriptif kuantitatif. Data yang dikumpulkan melalui questionarredianalisis dengan analisis statistik deskriptif.Penelitian dilakukan tidak untuk menguji hipotesis tetapi mendeskripsikan data kuantitatif berbentuk distribusi data persentasi.

Objek penelitian ini adalah pandangan mahasiswa baru tentang elemen-elemen bauran pemasaran jasa pendidikan yaitu produk (product), biaya (price), tempat (place), promosi (promotion), warga kampus (people), bukti fisik (physical evidence), dan proses (process). Dari pandangan tersebut dapat dilihat alasan mengapa mereka melanjutkan studi di IAIN Antasari.

Populasi yang menjadi target pada penelitian ini adalah seluruh mahasiswa baru IAIN Antasari tahun 2013. Pemilihan mahasiswa baru sebagai populasi penelitian berdasarkan asumsi mereka relatif baru menjadi mahasiswa IAIN Antasari sehingga masih ingat tentang elemen-elemen bauran pemasaran. Peneliti beranggapan bahwa jika mahasiswa yang sudah lama kuliah dipilih sebagai populasi penelitian, jawaban mereka tidak sebagai pengakuan tetapi lebih sebagai evaluasi terhadap elemen bauran pemasaran. Dengan kata lain, populasi tersebut dipilih berdasarkan asumsi bahwa mahasiswa baru belum dipengaruhi oleh proses pembelajaran di IAIN Antasari. Dengan demikian, pendapat mereka tentang unsur-unsur bauran pemasaran lebih dapat dipertanggungjawabkan. 
TABEL 3.1

POPULASI DAN SAMPLE PENELITIAN

\begin{tabular}{|r|l|l|l|}
\hline No & \multicolumn{1}{|c|}{ Fakultas } & \multicolumn{1}{|c|}{ Populasi } & \multicolumn{1}{|c|}{ Sample } \\
\hline 1 & Fakultas Dakwah dan Komunikasi & 67 & 22 \\
\hline 2 & Fak. Syariah dan Ekonomi Islam & 424 & 138 \\
\hline 3 & Fak. Tarbiyah dan Keguruan & 979 & 320 \\
\hline 4 & Fak. Ushuluddin dan Humaniora & 108 & 35 \\
\hline & & 1578 & 515 \\
\hline
\end{tabular}

Jumlah populasi 1578 orang dapat ditarik sampel 469 orang dengan taraf kesalahan lebih rendah dari 1\%. (Sugiyono, 2011 : 131) Pada penelitian ini, jumlah sampel ditetapkan 515 responden lebih banyak dari tabel yang dibuat Sugiyono (2011) sehingga tingkat kesalahan bisa dikurangi serendah mungkin.

\section{F. HASIL PENELITIAN}

Pada bagian ini akan dipaparkan data hasil penelitian yang berhubungan dengan tanggapan responden tentang elemen bauran pemasaran jasa pendidikan. Elemen yang memenuhi harapan merupakan alasan atau pendorong mereka melanjutkan kuliah di IAIN Antasari. Pada bagian diatas telah dipresentasikan temuan penelitian yang menunjukkan pengakuan responden tentang elemen apa yang mereka anggap paling memenuhi harapan mereka. Dari sudut pandang bauran pemasaran, elemen-elemen tersebut yang menjadi alasan mereka untuk memilih IAIN Antasari sebagai perguruan tinggi tempat mereka melanjutkan studi. Dengan kata lain, elemen yang memiliki ratarata paling tinggi dapat diduga merupakan alasan paling kuat mereka mengapa mereka melanjutkan studi di IAIN Antasari. Sebaliknya, elemen yang paling rendah merupakan elemen yang harus diperbaiki untuk meningkatkan minat calon mahasiswa melanjutkan kuliah di IAIN Antasari.

Pada tabel berikut dapat dilihat peringkat rata-rata elemen bauran pemasaran dari yang paling tinggi.

TABEL 4.28

PERINGKAT ELEMEN BAURAN PEMASARAN

\begin{tabular}{|l|l|l|}
\hline PERINGKAT & ELEMEN & RATA-RATA \\
\hline Pertama & Produk (product) & 92,12 \\
\hline Kedua & Warga kampus (people) & 81,66 \\
\hline Ketiga & Biaya (price) & 81,31 \\
\hline Keempat & Bukti fisik (Physical evidence) & 77,21 \\
\hline Kelima & Tempat (place) & 67,24 \\
\hline Keenam & Proses (process) & 67,06 \\
\hline Ketujuh & Promosi (promotion) & 62,27 \\
\hline
\end{tabular}


Bagian ini akan mendiskusikan tentang elemen-elemen bauran pemasaran yang telah dipaparkan pada bagian terdahulu.

\section{Produk (Product)}

Penelitian ini menunjukkan bahwa elemen produk merupakan elemen yang paling banyak diakui mahasiswa, rata-rata $92,12 \%$ sebagai pendorong mereka melanjutkan kuliah di IAIN Antasari. Produk pendidikan dapat meliputi aspek kualitas, fitur pada produk, pilihan, model, sizes produk, layanan, garansi, pengembalian, dan merek. (Kotler, 2002 :10) Dalam konteks administrasi pendidikan, produk merupakan pendorong paling fundamental dan menjadi preferensi pilihan bagi calon mahasiswa.

Jika merujuk pada hal penelitian ini dan pendapat Kotler (2002 : 10), strategi yang paling punya peluang untuk meningkan kuantitas mahasiswa adalah memberikan pilihan jurusan yang lebih banyak bagi calon mahasiswa. Diferiansi jurusan akan membuka peluang kerja yang lebih luas bagi lulusan perguruan tinggi. Dampak lebih jauh adalah akan lebih memperkuat citra/reputasi, atau dalam istilah Kotler disebut brand, yang akan menjadi pendorong calon mahasiswa memilih perguruan tinggi.

Alma (2005 : 116) menambahkan elemen produk tidak hanya menyangkut produk akademik juga, tetapi juga produk yang membuat layanan pendidikan lebih bervariasi misalnya kegiatan olahraga, kesenian, keagamaan, dan kursus-kursus.

\section{Biaya (Price)}

Mencermati elemen biaya, penelitian ini menunjukkan bahwa biaya kuliah turut berandil mendorong calon mahasiswa memilih di IAIN Antasari. Dengan kata lain, rata-rata elemen biaya sebesar 81,31\% mempresentasikan mahasiswa IAIN Antasari merasa biaya yang selama ini mereka bayar memenuhi harapan mereka. Terlepas dari hal tersebur, biaya yang murah tidak dapat dipastikan menjadi alasan utama calon mahasiswa memilih kuliah disebuah perguruan tinggi. Biaya beriringan dengan kualitas produk. Hal itu berarti, produk yang berkualitas dapat dijadikan dasar untuk meningkatkan biaya, dalam hal ini SPP. SPP yang besar tidak akan mengurangi jumlah mahasiswa, ketika kebijakan itu diiringi dengan meningkatnya kualitas produk dan elemen pada produk tersebut.

Dalam konteks harga yang tinggi tersebut, dikenal istilah price skimming. Price skimming digunakan pada saat permintaan meningkat yang diiringi dengan kualitas produk. Asumsi bahwa mahasiswa IAIN Antasari berlatar belakang ekonomi menengah ke bawah disebabkah oleh SPP yang rendah tersebut. Dengan price skimming asumsi itu dapat diubah. Segmentasi pasar untuk kalangan menengah ke bawah akan berubah jika SPP disesuaikan dengan SPP perguruan tinggi lain di Kalimantan Selatan.

Dalam sudut pandang strategi price skimming, memberi kesempatan untuk calon mahasiswa yang kurang mampu tidak dengan SPP yang murah, tetapi dengan memberikan bantuan yang lebih banyak kepada mereka melalui beasiswa atau bantuan yang bersifat pribadi. Kotler (2002 : 217) menungkapkan bahwa pada lembaga non profit, price 
skimming dapat dilakukan dengan private gifts and public grants to cover the remaining costs. Huimin dan Hernandez (2011 : 393) mengingatkan bahwa price skimming dapat digunakan ketika harga yang tinggi diinterpretasikan sebagai tandan kualitas yang tinggi dan status.

Kelemahan strategi price skimming ini adalah membuk peluang bagi kompetitor untuk menarik calon mahasiswa. Hal itu disinyalir oleh (Huimin dan Hernandez, 2011 :392). Ia menyebutkah bahwa harga yang tinggi menarik kompetitor untuk secepatnya mengambil peluang tersebut. Dengan kata lain, jika price skimming dilakukan oleh IAIN Antasari, akan terbuka bagi perguruan tinggi agama Islam (PTAI) lain untuk menarik calon mahasiswa dengan SPP yang lebih murah.

\section{Tempat (Place)}

Pemaparan data dibagian terdahulu telah disebutkan bahwa rata-rata elemen tempat adalah 67,24\%. Rata-rata yang relatif rendah dari elemen produk dan harga tersebut menunjukkan bahwa calon mahasiswa akan tetap memilih melanjutkan kuliah di IAIN Antasari, meskipun lokasi tidak memenuhi keinginan mereka. Meskipun, kampus pindah ke lokasi lain, calon mahasiswa tetap akan melanjutkan kuliah di IAIN Antasari, jika harapan mereka terhadap produk dapat dipenuhi.

Terlepas dari hal tersebut, hal yang perlu dicermati dari elemen tempat ini adalah kemudahan menuju lokasi kampus. Kampus harus terhubung dengan tempat publik lain oleh sarana trasportasi umum serta akses jalan yang mudah dilalui.

\section{Promosi (Promotion)}

Rata-rata elemen promosi yang berada pada kriteria cukup 62,27\% mempresentasikan tingkat promosi IAIN Antasari. Itu bermakna ganda jika dikaitkan dengan jumlah mahasiswa baru. Makna pertama adalah promosi yang dilakukan belum optimal dalam penyebaran informasi tentang penerimaan mahasiswa baru IAIN Antasari. Pada item-item elemen promosi telah ditunjukkan bahwa bentuk promosi yang paling banyak sampai ke calon mahasiswa. Jika dibuat peringkat dari sumber informasi tertinggi adalah

a. mahasiswa $77,47 \%$

b. brosur $75,73 \%$

c. guru $75,73 \%$

d. sosialisasi kunjungan ke sekolah madrasah 59,03\%

e. media massa $52,43 \%$

f. dosen/tenaga administrasi $33,21 \%$

Informasi melalui kunjungan ke sekolah/madrasah yang sangat rendah berhubungan dengan waktu yang tidak tepat. Sosialisasi datang terlambat dibandingkan dengan lembaga pendidikan lain. Rendahnya partisipasi dosen/tenaga administrasi dalam promosi tersebut dapat menjadi indikasi awal rendahnya tingkat loyalitas dosen/tenaga 
administrasi terhadap institusi. Sebaliknya peran guru sangat besar dalam promosi. Peneliti menduga guru-guru yang aktif memberi informasi tersebut adalah guru alumni IAIN Antasari. Oleh karena itulah, membandingkan loyalitas alumni dengan dosen/ tenaga administrasi dari aspek "penyampaian positif dan refers other" menarik untuk diteliti lebih jauh pada masa akan datang.

Makna kedua adalah promosi bukan merupakan hal yang menjadi pendorong calon mahasiswa dalam memilih perguruan tinggi. Makna kedua ini perlu digarisbawahi karena promosi yang berlebihan ternyata berkorelasi negatif daya tarik peminat. Perguruan tinggi swasta yang kuat melaksanakan promosi lebih rendah daripada perguruan tinggi yang kuat (Alma, 2005 : 117)

Pola sosialisasi yang layak untuk dipertimbangkan adalah dengan melibatkan mahasiswa. Partisipasi mahasiswa dalam sosialisasi dipraktikkan oleh Fakultas Syariah dan Ekonomi Islam. Mashunah Hanafi menyebutkan bahwa proses sosialisasi dengan melibatkan mahasiswa lama lebih mudah dan efektif. Biaya yang dikeluarkan untuk sosialisasi yang dilakukan mahasiswa relatif lebih murah daripada melibatkan para dosen. Apalagi jika dilihat pengakuan mahasiswa baru yang hanya 59,03\% mendapat informasi dari sosialisasi ke sekolah.

\section{Warga Kampus (People)}

Pada bagian terdahulu telah disebutkan bahwa rata-rata elemen warga kampus (people) yaitu sumber daya manusia: dosen dan tenaga administrasi, serta mahasiswa lain adalah pada kriteria tinggi yaitu 81,66\%. Mahasiswa beranggapan bahwa seluruh warga kampus sesuai dengan harapan mereka sehingga mereka memilih melanjutkan kuliah di IAIN Antasari. Warga kampus tidak hanya yang berhubungan dengan sumber daya manusia: dosen dan tenaga administrasi saja, tetapi juga costumer lain, dalam hal ini teman sesama mahasiswa.

Penelitian ini menunjukkan fakta emperik bahwa mahasiswa merasa bangga jika ada mahasiswa yang berprestasi bidang olahraga dan akademik. Implikasi dari temuan ini adalah pemasaran jasa pendidikan dapat diiringi dengan jalur undangan prestasi non akademik. Para lulusan SMA/MA yang berprestasi pada bidang olahraga dapat diundang untuk melanjutkan kuliah di IAIN Antasari dengan tawaran beasiswa. Praktik semacam itu telah dilakukan oleh universitas-universitas besar.

Posisi warga kampus dalam mempengaruhi calon mahasiswa dalam memilih perguruan tinggi dapat dilihat pada gambar berikut 
GAMBAR 4.1

\section{UNSUR YANG MEMPENGARUHI CALON MAHASISWA}

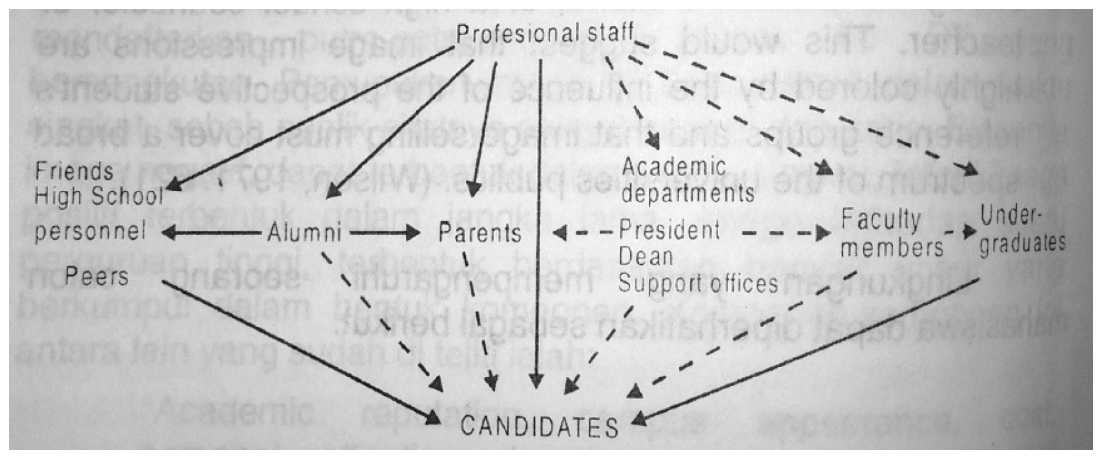

Sumber :Alma, $2005: 96$

Pada gambar tersebut yang dapat mempengaruhi calon mahasiswa adalah warga kampus yaitu pimpinan, dosen/staf, serta mahasiswa. Pada gambar tersebut juga dapat dilihat bahwa pihak perguruan tinggi harus memberikan informasi kepada calon mahasiswa melalui adalah siswa, alumni, dan orang tua. Alumni dalam model diatas memiliki peran sangat besar. Alumni berperan mempengaruhi orang tua dan para guru/ siswa disebuah sekolah.

\section{Bukti Fisik (Physical Evidence)}

Rata-rata elemen bukti fisik sebanyak 77,21\% menunjukkan bahwa mahasiswa beranggapan bangunan dan lingkungan IAIN Antasari cukup memenuhi harapan mereka. Meskipun demikian, rata-rata elemen ini yang masih di bawah 80\% harus ditingkatkan lagi. Bukti fisik ini lebih kepada penampilan fisik dan lingkungan tempat terjadinya interaksi penyedia jasa dengan customer; mahasiswa.

Bukti fisik ini berhubungan dengan "janji” yang disampaikan melalui elemen promosi. Promosi mengemukakan fasilitas yang tersedia dan dibuktikan dengan penampilan dan kelengkapan sarana, ketika calon mahasiswa mengunjungi kampus. Janji pada promosi yang tidak sesuai dengan bukti fisik akan mengecewakan calon mahasiswa dan tidak mustahil mereka akan berpindah ke perguruan tinggi lain.

\section{Proses (Process)}

Penelitian ini juga menunjukkan bahwa elemen proses berada pada rata-rata 67,06\%. Hal itu, menjadi kritik bagi seluruh proses pelayanan bagi mahasiswa. Proses ini menyangkut bagaimana penyerahan jasa kepada pelanggan. Ini berbeda dengan elemen people yang lebih menunjukkan kepada "orang". Dengan demikian, perhatian utama pada proses ini adalah bagaimana kecepatan pelayanan kepada masyarakat. Pada proses perkuliahan yang harus diperhatikan adalah bagaimana perkuliahan tersebut dilaksanakan oleh dosen. 
Oleh karena itu, proses sangat berhubungan dengan elemen people. Proses dilaksanakan oleh people, dosen melaksanakan proses perkuliahan dan tenaga administrasi melaksanakan proses pelayanan administrasi. Alma (2005: 120) menyebutkan 5 sifat dominan yang dharus dimiliki people dalam kaitannya dengan proses: reliability, yaitu kemampuan memberikan jasa sesuai dengan yang dijanjikan; responsiveness, yaitu kemampuan memberikan jasa layanan yang cepat, dan tanggap atas keluhan yang disampaikan secara resmi ataupun berupa keluhan; assurance yaitu memberi keyakinan dan kepercayaan kepada mahasiswa; emphaty yaitu ada kepedulian dan konsen terhadap mahasiswa sebagai konsumen; dan tangible yaitu penampilan fasilitas fisik, peralatan, dan berbagai media pengajaran yang cukup berperan dalam proses belajar mengajar.

\section{G. PENUTUP}

Penelitian ini menyimpulkan bahwa masih ditemukan elemen-elemen bauran pemasaran (marketing mix) yang masih dianggap responden belum memenuhi harapan mereka yaitu elemen promosi, proses, dan tempat.

\section{DAFTAR PUSTAKA}

Alma, Buchari. (2005). Pemasaran Stratejik Jasa Pendidikan, Bandung : Alfa Beta

Bray, Mark, (2008). Double-shift Schooling: Design and Operation for Cost Effectiveness, Third Edition, Paris : UNESCO

Griffin, Jill. (2002). Customer Loyalty: How To Earn It, How To Keep It, San Francisco : Jossey Bass

Hariyanto, dkk. (2007) Faktor-Faktor Yang Mempengaruhi Mahasiswa Memasuki IAIN Antasari Banjarmasin, Hasil Penelitian, Banjarmasin : Pusat Penelitian IAIN Antasari

Hidayat, Ara. \& Machali, Imam. (2012). Pengelolaan Pendidikan, Yogyakarta : Kaukaba Huimin,M, dan Hernandez, (2011) Jose Antonio, Price Skimming on a Successful Marketing Strategy: Study of Ipad Launching as Apple's Innovative Product, Proceedings of the 8th International Conference on Innovation \& Management

IAIN Antasari. (2012). Data dan Statistik. IAIN Antasari Banjarmasin Tabun 2012, Banjarmasin : IAIN Antasari.

John F. Witte (2000). The Market Approach To Education, Princeton, New Jersey 08540 : Princeton University Press

Kotler, Philip. (2000). Marketing Management, Millenium Edition, New York : Prentice Hall

Kotler, Philip. (2002). Marketing Management, Millenium Edition. Boston : Pearson 
Sallis. Edward (2002). Total Quality Management in Education, 3th Edition, London: Kogan Page Ltd

The Chartered Institutef of Marketing. (2009). How to Achieve an Effective Marketing Mix, Berkshire UK: The Chartered Institutef of Marketing 
